\title{
Analisis Sebaran Parameter Kualitas Air dan Indeks Pencemaran di Perairan Teluk Parepare-Sulawesi Selatan
}

\author{
Dian N Handiani ${ }^{1}$ dan Aida Heriati²
}

\author{
1Institut Teknologi Nasional, Bandung; e-mail: ddhandiani@itenas.ac.id \\ 2Pusat Riset Kelautan, Badan Riset dan Sumber Daya Manusia Kelautan dan Perikanan Kementrian \\ Kelautan dan Perikanan
}

\begin{abstract}
ABSTRAK
Teluk Parepare di Sulawesi Selatan merupakan kawasan dengan aktivitas pelabuhan penumpang dan kargo, serta perikanan yang produktif. Aktifitas ini berdampak terhadap ekologi di perairan tersebut. Pesisir dan laut secara ekologi memiliki fungsi penting bagi kehidupan manusia. Salah satunya fungsi siklus biogeokimia dari buangan limbah yang masuk ke perairan tersebut. Akan tetapi, kebermanfaatan ini hendaknya tidak melebihi kapasitas ekologinya dalam menerima suatu jumlah limbah. Jika berlebih, maka akan terjadi kerusakan lingkungan dan kesehatan yang sulit ditoleransi. Kondisi ini mempersulit perairan tersebut untuk mewujudkan pembangunan berkelanjutan dan berkesesuaian dengan lingkungan. Penelitian ini bertujuan menganalisis sebaran spasial parameter kualitas air laut dan indeks pencemaran di perairan Teluk Parepare, serta sebagai upaya membantu pemerintah setempat melakukan pengawasan dan pengendalian pencemaran di perairan tersebut. Penelitian ini memanfaatkan hasil pengukuran in situ enam parameter (suhu, salinitas, pH, ammonia, timbal dan tembaga) di 28 stasiun pengamatan. Parameter tersebut mencakup baku mutu peruntukkan wilayah pelabuhan dan mengingat di kawasan tersebut terdapat juga aktivitas kilang minyak. Sebaran spasial parameter kualitas perairan merupakan hasil interpolasi dengan metode Inverse Distance Weighted (IDW) dari hasil pengukuran lapangan dan dihitung indeks pencemarannya. Hasil menunjukkan sebaran suhu, salinitas, ammonia, dan pH terlarut berkesesuaian dengan baku mutu, sedangkan konsentrasi timbal dan tembaga (logam berat) berada di atas baku mutu. Indeks pencemaran (IP) menghasilkan nilai antara 1,69-38,66. Nilai IP diklasifikasikan menjadi indeks cemar ringan di 14 stasiun pengamatan dan sebaran cemar ringan dominan di Teluk Parepare bagian dalam. Indeks cemar sedang terdapat di 12 stasiun pengamatan dan sebarannya di Teluk Parepare bagian luar, sedangkan cemar berat terdapat di 2 stasiun dan sebarannya di sekitar pesisir Kota Parepare. Kondisi ini menunjukkan bahwa parameter logam berat (seperti timbal dan tembaga) telah melebihi baku mutu dan berkaitan dengan berbagai kegiatan pelabuhan, serta perkapalan di sekitar perairan Teluk Parepare.
\end{abstract}

Kata $\boldsymbol{k u n c i : ~ i n d e k s ~ p e n c e m a r a n , ~ k u a l i t a s ~ a i r , ~ t e l u k ~ p a r e p a r e , ~ l o g a m ~ b e r a t ~}$

\begin{abstract}
Parepare Bay in South Celebes is an area with one of the busiest ports and fisheries activities. These activities influence ecological system of the bay. In return, the coastal area also has various ecological functions which can benefit human. This includes the biogeochemical cycling of waste disposed into the area. This function must not exceeds the ecological capacity of the coastal area, therefore the amount of waste needs to be limited under certain threshold. Exceeding the threshold would damage the coastal health and environment, and would render impossible in obtaining a sustainable development and suitably functioning environment. This study aims to analyze water quality and to determine water pollution index at Parepare Bay in order to aid the local government in managing and controlling pollution within the Parepare Bay. Six parameters of water quality were measured at 28 stations; temperature, salinity, $\mathrm{pH}$, ammonia, lead, and copper concentrations. These parameters were compared with standard sea water quality for harbor activities. The parameters were interpolated using Inverse Distance Weighted (IDW) method and afterwards, the pollution index was calculated. Spatial distribution of temperature, salinity, $\mathrm{pH}$ and ammonia were still appropriate for harbor activities in all stations. However, lead and copper were over the normal amount. Pollution index at Parepare Bay were in the range between 1,69-38,66. Spatial distribution of the indexes were classified as lightly polluted in 14 stations and the distribution was located dominantly within the Parepare Bay. Twelve stations were moderately polluted, distributed mainly outside of the Parepare Bay, while 2 sampling stations were found to be highly polluted with area near the coast of Parepare City. It is important to notice that the parameters of quality standards which had been exceed such as lead and copper are might be related to contamination of pollutant from ports and shipping activities.
\end{abstract}

Keywords: pollutant index, water quality, Parepare Bay, heavy metal

Citation: Handiani, D.N. dan Heriati, A. (2020). Analisis Sebaran Parameter Kualitas Air dan Indeks Pencemaran di Perairan Teluk Parepare. Jurnal Ilmu Lingkungan, 18(2), 272-282, doi:10.14710/jil.18.2.272-282 


\section{Pendahuluan}

Pembangunan ekonomi di wilayah pesisir dan laut tanpa diimbangi dengan perlindungan terhadap sumber daya alam yang ada, maka akan berbalik mengancam kehidupan manusia dan seluruh sistem kehidupan/lingkungan lainnya (Diposaptono, 2016). Kondisi ini mengharuskan pembangunan yang dilakukan memiliki konsep pengelolaan yang berkelanjutan. Integrated Coastal Management (ICM) atau Pengelolaan Wilayah Pesisir secara Terpadu (PWPT) merupakan konsep model paling tepat dalam pengelolaan wilayah pesisir dan laut berkelanjutan (Diposaptono, 2016). Pengelolaan berkelanjutan tersebut hendaknya menerapkan empat prinsip, yaitu ekologis, ekonomi, sosial politik, serta hukum dan kelembagaan (Dahuri dkk., 2003 dan Diposaptono, 2016).

Dalam prakteknya, keempat prinsip tersebut diaplikasikan pada pengelolaan pesisir berkelanjutan ICM atau PWPT menjadi lima tahapan, yaitu identi- fikasi dan penaksiran isu/masalah, perencanaan program pengelolaan, pelaksanaan/implementasi, adopsi pengetahuan dan keuangan, serta evaluasi. Kelima tahapan tersebut terus berulang untuk mencapai tujuan utama pengelolaan berkelanjutan (Gambar 1).

Di tahap awal, proses identifikasi dan penaksiran isu yang timbul, dilakukan pada semua prinsip pengelolaan berkelanjutan. Prinsip ekologi dari kondisi sistem di pesisir yang diidentifikasi dan ditaksir (kotak dan garis biru di Gambar 1) adalah karakteristik signifikan dari habitat, spesies, dan komunitas biologi pesisir, trend kondisi dan penggunaan sumber daya yang ada, dampak jangka pendek dan panjang dari berbagai perubahan di lingkungan dan komunitas masyarakat pesisir, serta identifikasi kondisi pada suatu wilayah di pesisir yang dianggap penting untuk dikelola melalui ICM/TPWP (GESAMP, 1996).

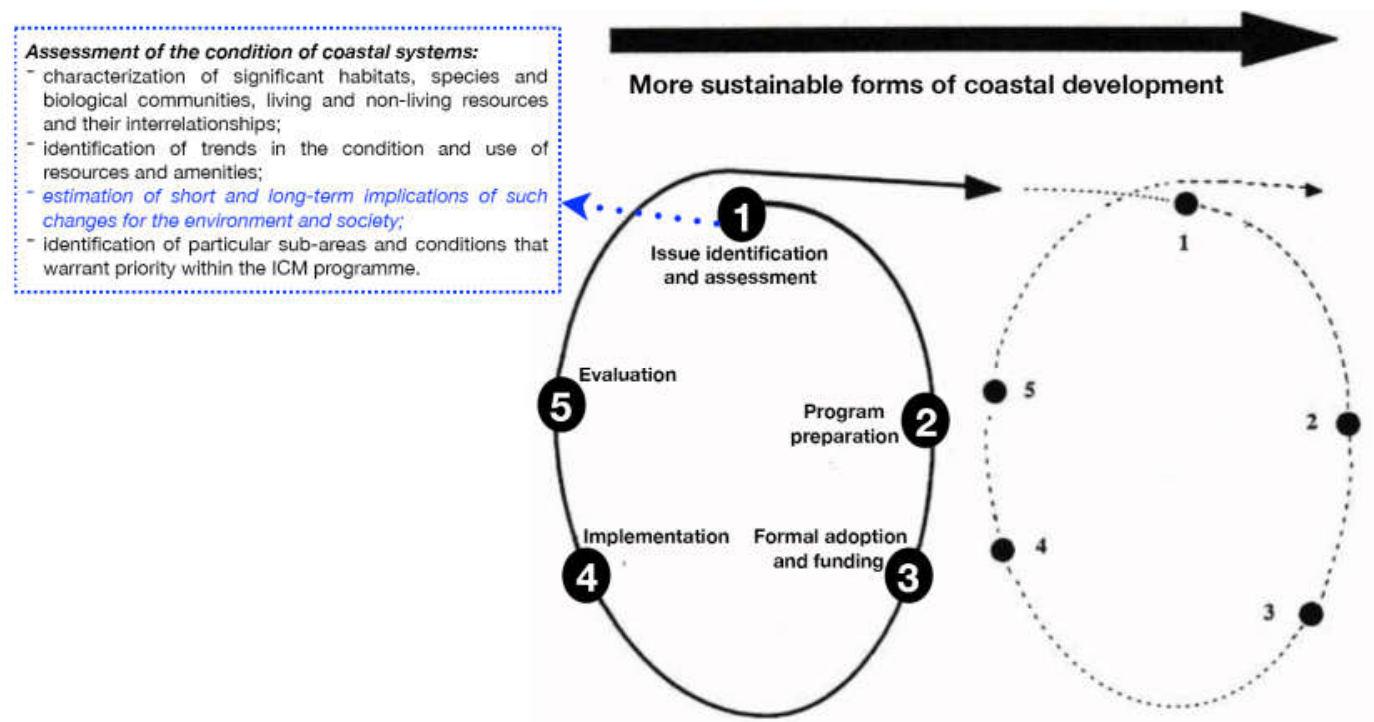

Gambar 1. Tahapan Aplikasi Pengelolaan Wilayah Pesisir Berkelanjutan dan Pentingnya Estimasi Dampak Perubahan di Lingkungan Pesisir (Sumber: Adaptasi dari GESAMP, 1996)

Bengen (2004) menyatakan bahwa dalam pengelolaannya, kawasan pesisir banyak dipengaruhi oleh faktor eksternal di sekitar kawasan pesisir yang pada akhirnya dapat menimbulkan dampak baik secara langsung maupun tidak langsung, serta berdampak jangka pendek maupun panjang. Dampak yang ditimbulkan ini diantaranya adalah bahan pencemar atau sedimen yang masuk ke pesisir Keterkaitan masuknya bahan pencemar dan dampaknya terhadap kawasan ini perlu untuk diketahui dan dipelajari sebagai tahapan awal pengaplikasian dari pengelolaan wilayah pesisir dan pada akhirnya bisa mewujudkan minimalisir dampak yang terjadi pada kawasan pesisir.

Teluk Parepare merupakan kawasan perairan potensial di Sulawesi Selatan. Berbagai aktivitas di perairan tersebut diantaranya pusat pelayanan pelabuhan (Amaliah dkk., 2018), perikanan tangkap dan budidaya (Malik dkk., 2018; Fattah dkk., 2017), dan pariwisata (Mappagala, 2017). Tingginya aktivitas di perairan tersebut mempengaruhi dan berpotensi timbulnya pencemaran di perairan Teluk Parepare. Pencemaran laut didefinisikan sebagai pengaruh negatif dari pembuangan limbah ke dalam laut dan menurut Diposaptono (2016) wilayah perairan Sulawesi Selatan yang salah satunya perairan Teluk Parepare tergolong memiliki tingkat pencemaran laut yang tinggi. Beberapa penelitian terkait pencemaran di perairan sekitar Teluk Parepare telah dilakukan (Usman dkk., 2013; Setiawan dan Subiandono, 2015; Wisha dkk., 2018). Akan tetapi, sifatnya terbatas hanya membahas satu atau beberapa parameter kualitas perairan, serta lingkup areanya pun terbatas, karena umumnya penelitian dilakukan melalui survei lapangan.

Penelitian saat ini mengkaji sebaran beberapa parameter kualitas perairan (sesuai peraturan Kementerian Lingkungan Hidup No. 51, 2004) dan indeks pencemaran perairan (Hamuna dkk., 2018; Tanjung dkk., 2019) di perairan Teluk Parepare. Parameter tersebut didapatkan dari hasil survei lapangan di tahun 2015 (Wisha dan Heriati, 2016ab; 
Wisha dkk., 2018). Berdasarkan data-data yang tersedia kemudian diinterpolasi, dianalisis, dan dihitung indeks pencemaran sesuai batas baku mutu air laut untuk perairan pelabuhan (KemenLH, 2004). Sebaran dan indeks tersebut dipetakan secara spasial dengan memanfaatkan pengelolaan sistem informasi geografis.

Sebaran parameter kualitas perairan dan indeks pencemar di Teluk Parepare merupakan bagian dari tahap awal pengaplikasian ICM/PWPT di wilayah tersebut. Data hasil penelitian ini merupakan bagian dari identifikasi dan penaksiran dari dampak jangka pendek dan panjang dari perubahan lingkungan yang terjadi di perairan Teluk Parepare, dalam hal ini perubahan kualitas perairan. Identifikasi dan penaksiran isu yang ada di wilayah tersebut harapannya menjadikan wake-up called bagi para pengguna dan stakeholder setempat untuk memulai program pengelolaan pesisir yang berkelanjutan. Harapannya melalui pembangunan ekonomi yang diimbangi dengan pengelolaan lingkungan berkelanjutan, akan berdampak pada perkembangan ekonomi berkelanjutan pula.

Tersedianya data dan informasi terkait perubahan kualitas perairan di Teluk Parepare dapat membantu dibuat dan diimplementasikan kebijakan pengelolaan (ICM/PWPT) di wilayah tersebut. Sehingga, tercapai tujuan utama pembangunan wilayah pesisir berkelanjutan di perairan Teluk Parepare.

\section{Metodologi Penelitian}

Wilayah teluk, pantai, dan perairan sekitarnya memiliki peranan penting bagi aktivitas manusia.
Data UNEP (2015) menunjukkan setengah populasi di dunia bertempat tinggal dan beraktivitas dalam jarak $60 \mathrm{~km}$ dari garis pantai, sedangkan tiga perempat dari semua kota besar di dunia terletak di wilayah pesisir. Indonesia sendiri adalah negara kepulauan dan memiliki kota-kota yang berada di kawasan pesisir. Perairan Teluk Parepare terletak di pesisir Provinsi Sulawesi Selatan dan merupakan salah satu kawasan pesisir berpenduduk cukup padat. Di kawasan tersebut terletak Pelabuhan Cempae sebagai pelabuhan pendaratan ikan yang memiliki nilai penting bagi perekonomian wilayah sekitarnya.

Kajian studi mencakup area 3०58'30"-40.'35" Lintang Selatan dan 119³2'30"-119³7'30" Bujur Timur. Studi lapangan terkait kualitas perairan dilakukan pada tanggal 14-19 September 2015 di kawasan Teluk Parepare (Wisha dan Heriati, 2016ab; Wisha dkk., 2018). Pengukuran sampel air dilakukan secara purposive sampling dengan menggunakan alat multiparameter WQC-24 merk TOA-DKK secara in situ. Beberapa parameter kualitas fisika-kimia air laut yang diukur diantaranya, temperatur, salinitas, dan pH. Sampel air tersebut juga dianalisis kandungan nutrien ammonia $\left(\mathrm{NH}_{3}\right)$, serta logam berat terlarut, yaitu Timbal $(\mathrm{Pb})$ dan Tembaga $(\mathrm{Cu})$. Lokasi stasiun pengambilan sampel dimulai dari dalam Teluk Parepare bergerak ke arah barat, selatan, dan sampai ke luar dari teluk/perairan bebas (S1-S28). Stasiun S1-S18 berada di dalam teluk, sedangkan S19-S28 di luar Teluk atau di Selat Sulawesi (Gambar 2).

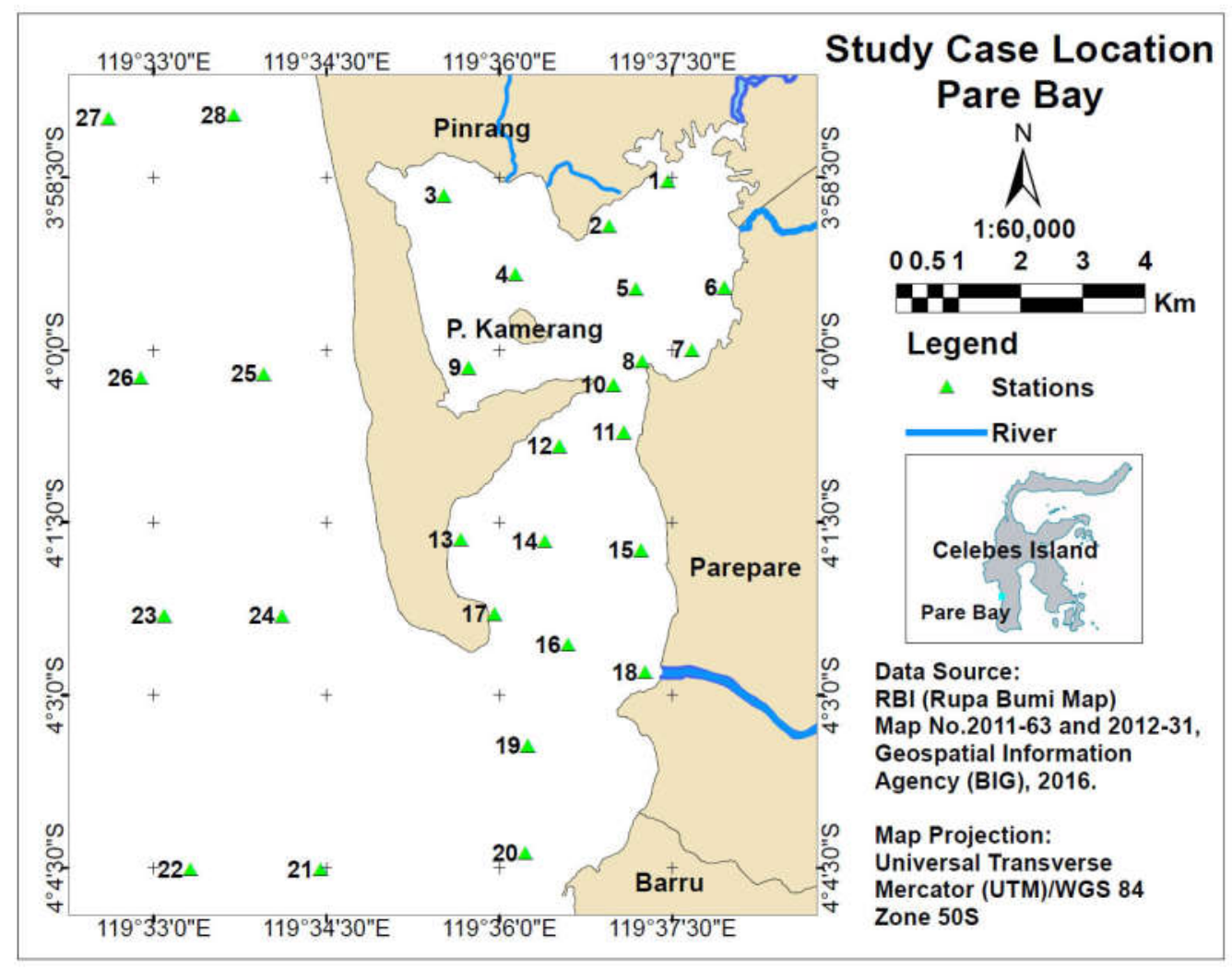

Gambar 2 Lokasi Kajian dan Stasiun Pengambilan Sampel di Lapangan 
Analisis sebaran kualitas perairan di lokasi kajian dilakukan dengan menginterpolasi titik pengamatan S1-S28. Metode interpolasi yang dipilih adalah Inverse Distance Weighted (IDW) sesuai dengan Standar Nasional Indonesia (SNI 7644:2010) terkait penyediaan basis data spasial oseanografi. Metode IDW menghitung lebih cepat dibandingkan metode lainnya (contohnya kriging), meskipun kualitas perhitungannya dalam kategori acceptable (Qin dan Lin, 2017). Metode ini mengasumsikan nilai hasil interpolasi mirip dengan data sampel yang berdekatan dibandingkan dengan yang berjauhan, jarak antara titik yang dihitung terhadap referensi mempengaruhi bobot (weight) perhitungan interoplasinya (Childs, 2004). Keuntungan menggunakan metode ini adalah nilai hasil interpolasi terbatas pada nilai yang terdapat pada data sampel, sehingga tidak akan ditemui nilai di luar dari data pengamatan. Selain itu, titik pengamatan tersebar di seluruh wilayah kajian dan berjumlah lebih dari 10 titik pengamatan (jumlah titik minimal pengamatan untuk dilakukan interpolasi sesuai SNI (2010)).

Rumus persamaan sebaran indeks pencemaran berikut:

$P I_{j}=\sqrt{\frac{\left(C_{i} / L_{i j}\right)_{M}^{2}+\left(C_{i} / L_{i j}\right)_{R}^{2}}{2}}$

\begin{tabular}{|c|c|c|}
\hline$L_{i j}$ & : & $\begin{array}{l}\text { konsentrasi parameter kualitas air } \\
\text { yang ditentukan dalam baku mutu } \\
\text { peruntukkannya }(j)\end{array}$ \\
\hline$P_{i j}$ & : & $\begin{array}{l}\text { indeks pencemaran (pollution index) } \\
\text { bagi peruntukkannya }(j)\end{array}$ \\
\hline$C_{i}$ & . & $\begin{array}{l}\text { konsentrasi parameter kualitas air di } \\
\text { lapangan }\end{array}$ \\
\hline$\left(C_{i} / L_{i j}\right)_{M}$ & . & nilai $C i / L i j$ maksimum \\
\hline$\left(C_{i} / L_{i j}\right)_{R}$ & & nilai $C i / L i j$ rata-rata \\
\hline
\end{tabular}

Nilai indeks pencemaran dikategorikan berdasarkan Keputusan Mentri Lingkungan Hidup No. 115 tahun 2003 dan ditunjukkan dalam Tabel 1.

Tabel 1. Kategori Nilai Indeks Pencemaran

\begin{tabular}{cc}
\hline \hline Nilai Indeks & Kategori \\
\hline $0 \leq \mathrm{PIj} \leq 1,0$ & Baik (memenuhi baku mutu) \\
$1,0<\mathrm{PIj} \leq 5,0$ & Cemar Ringan \\
$5,0<\mathrm{PIj} \leq 10$ & Cemar Sedang \\
$\mathrm{PIj}>10$ & Cemar Berat \\
\hline Sumber: Keputusan MenLH No. 115 tahun 2003
\end{tabular}

\section{Hasil dan Pembahasan}

\subsection{Kesesuaian Parameter Kualitas Air Laut} untuk Pelabuhan di Perairan Teluk Parepare

Parameter kualitas air yang diukur mencakup fisika-kimia perairan (suhu, salinitas, $\mathrm{pH}$, dan ammonia) dan kondisi logam berat terlarut (timbal dan tembaga). Ke enam parameter tersebut termasuk dalam parameter baku mutu air laut peruntukkan pelabuhan, sehingga dalam kajian ini mengacu pada baku mutu tersebut (KemenLH, 2004), ditunjukkan di Tabel 2. Kajian semua parameter kualitas air di perairan Teluk Parepare juga digambarkan melalui grafik histogram Gambar 3a-3f. Histogram menunjukkan tidak semua parameter tersebar dari nilai terbesar dan terkecil. Sebagian data berada di nilai maksimumnya (Gambar 3b, frekuensi $=26$ ) dan nilai minimumnya (Gambar 3e, frekuensi $=16$ ).

Tabel 2. Kategori Nilai Indeks Pencemaran

\begin{tabular}{clll}
\hline \hline No. & Parameter & $\begin{array}{l}\text { Baku } \\
\text { Mutu* }\end{array}$ & $\begin{array}{c}\text { Perairan Teluk } \\
\text { Parepare** }\end{array}$ \\
\hline 1. & Suhu (derajat) & Alami & $27,2-28,6$ \\
2. & Salinitas (psu) & Alami & $20,5-32,9$ \\
3. & pH & $6,5-8,5$ & $7,47-7,93$ \\
4. & Nh3/Ammonia (mg/L) & 0,3 & $0,001-0,002$ \\
5. & Timbal/Pb (mg/L) & 0,05 & $0,111-2,692$ \\
6. & Tembaga/Cu (mg/L) & 0,05 & $0,043-0,078$ \\
\hline
\end{tabular}

* Sumber: Keputusan MenLH No. 51 tahun 2004;

** Sumber: Pengolahan data (2020)

Hasil pengukuran suhu di lokasi kajian berada berkisar 27,2 - 28,6 ${ }^{\circ} \mathrm{C}$ (Gambar 3a). Baku mutu suhu peruntukkan wilayah pelabuhan adalah kondisi alami perairan laut. Berdasarkan penelitian sebelumnya suhu alami permukaan laut dari hasil pengamatan satelit Aqua/Terra MODIS di Indonesia berada di kisaran 27,91 - 30,46 ${ }^{\circ} \mathrm{C}$ (Kusuma dkk., 2017). Hasil histogram kualitas air di perairan Teluk Parepare menunjukkan perairan tersebut masih dalam kisaran nilai untuk wilayah perairan tropis Indonesia. Salinitas terukur di lokasi kajian berkisar antara 20,5 - 32,9 psu (Gambar 3b) dan baku mutu yang diperkenankan untuk perairan pelabuhan adalah kondisi salinitas alami. Kondisi alami yang dimaksud adalah kondisi normal suatu lingkungan, bervariasi setiap saat (siang, malam dan musim). Wilayah pesisir Indonesia memiliki kondisi salinitas alami dalam kisaran 30,5 - 34 psu, berdasarkan data salinitas permukaan Satelit Aquarius (Toyoda dkk., 2015). Hasil pengukuran lapangan di dalam penelitian ini menunjukkan nilai terendah lebih kecil dari kondisi salinitas alami, akan tetapi nilai terbesar berada dalam kisaran normal wilayah pesisir tropis Indonesia.

Selanjutnya, nilai derajat keasaman $(\mathrm{pH})$ yang terukur di lokasi kajian berkisar 7,47 - 7,93 (Gambar 3c). Kisaran $\mathrm{pH}$ tersebut berada dalam kisaran batas baku mutu peruntukkan perairan pelabuhan. Hasil penelitian lainnya dan mencakup $\mathrm{pH}$ permukaan laut di perairan sekitar Teluk Parepare berada di kisaran 7,8-7,9 (Putri dkk., 2015). Hasil ini lebih tinggi dibandingkan hasil pengamatan lapangan yang dilakukan di penelitian ini. Nilai pH diatas $7(\mathrm{pH}>7)$ artinya perairan bersifat basa (Effendi, 2003). Umumnya perairan laut maupun pesisir memiliki $\mathrm{pH}$ dengan kisaran sempit dan bersifat basa atau disebut alkali (Brotowidjoyo dkk., 1995). Adapun, hasil pengukuran terhadap konsentrasi ammonia di perairan Teluk Parepare menunjukkan kisaran konsentrasi 0,001-0,002 mg/L (Gambar 3d). Nilai konsentrasi ini masih di bawah baku mutu yang ditetapkan. 

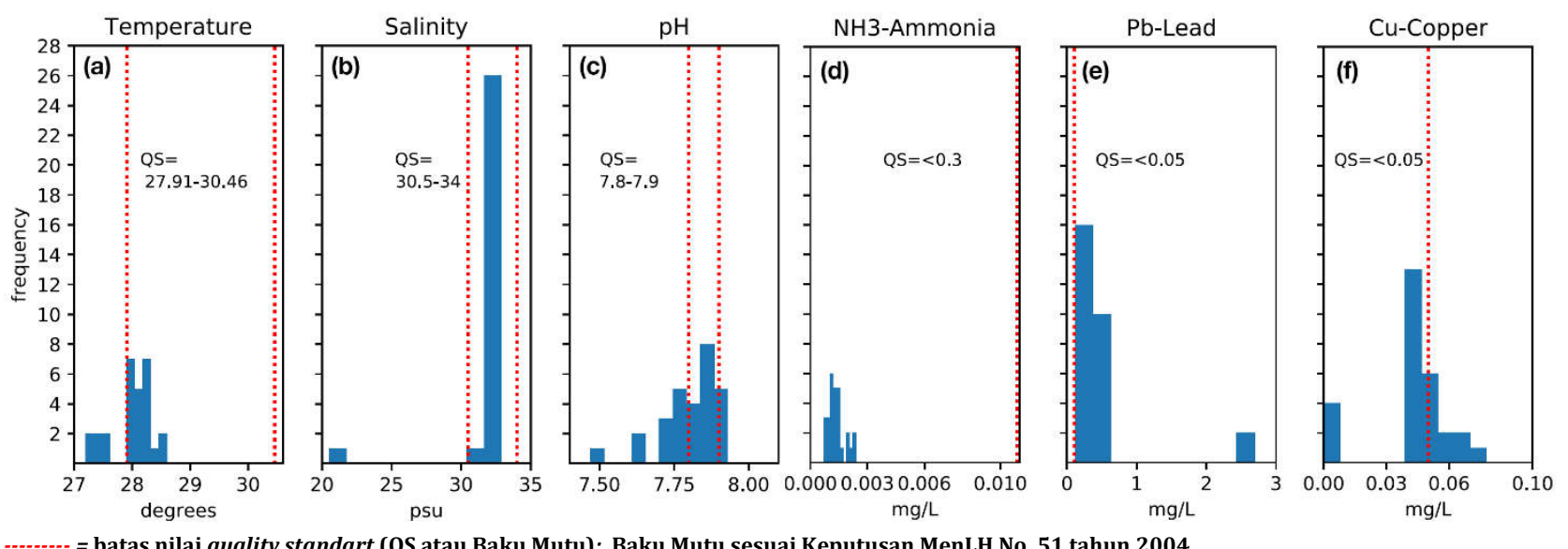

Gambar 3 Histogram Distribusi Parameter Kualitas Air Hasil Pengambilan Sampel Lapangan: (a) Suhu, (b) Salinitas, (c) pH, (d) Ammonia, (e) Timbal, dan (f) Tembaga.

Selanjutnya, nilai derajat keasaman $(\mathrm{pH})$ yang terukur di lokasi kajian berkisar 7,47 - 7,93 (Gambar 3c). Kisaran $\mathrm{pH}$ tersebut berada dalam kisaran batas baku mutu peruntukkan perairan pelabuhan. Hasil penelitian lainnya dan mencakup $\mathrm{pH}$ permukaan laut di perairan sekitar Teluk Parepare berada di kisaran 7,8-7,9 (Putri dkk., 2015). Hasil ini lebih tinggi dibandingkan hasil pengamatan lapangan yang dilakukan di penelitian ini. Nilai pH diatas $7(\mathrm{pH}>7)$ artinya perairan bersifat basa (Effendi, 2003). Umumnya perairan laut maupun pesisir memiliki $\mathrm{pH}$ dengan kisaran sempit dan bersifat basa atau disebut alkali (Brotowidjoyo dkk., 1995). Adapun, hasil pengukuran terhadap konsentrasi ammonia di perairan Teluk Parepare menunjukkan kisaran konsentrasi 0,001-0,002 mg/L (Gambar 3d). Nilai konsentrasi ini masih di bawah baku mutu yang ditetapkan.

Hasil pengukuran lapangan kandungan logam terlarut timbal (Gambar 3e) berkisar antara 0,111 2,692 mg/L. Konsentrasi ini berada di atas baku mutu yang ditetapkan, dimana seharusnya bernilai kurang atau maksimum 0,05 mg/L. Konsentrasi timbal tertinggi di Teluk Parepare berada di dua stasiun (S15 dan S16, Gambar 2e) dan stasiunnya lainnya kurang atau berada di kisaran nilai 0,5 mg/L. Adapun, konsentrasi tembaga di enam stasiun (S12, S15, S17, S21, S23, dan S26) memiliki konsentrasi di bawah baku mutu, dan lainnya memiliki nilai yang lebih besar dari baku mutu (Gambar 3f).

\subsection{Sebaran Parameter Kualitas Air di Perairan Teluk Parepare}

Sebaran parameter kualitas air laut di Teluk Parepare dibuat berdasarkan hasil interpolasi nilai parameter tersebut di S1 sd S28 (Gambar 4a-4b dan Gambar 5a-5b). Gambar 4a dan Gambar 4b menunjukkan parameter air laut suhu dan salinitas. Suhu lebih rendah terdeteksi di dalam perairan Teluk Parepare sebelah timur laut (perbatasan Kabupaten Pinrang dan Parepare) dan kondisi ini diakibatkan adanya supply air sungai yang mengalir dari dataran tinggi Parepare. Sedangkan, di dalam teluk di pantai selatan Kabupaten Pinrang suhu menunjukkan nilai yang lebih tinggi dibandingkan lokasi lainnya. Di bagian perairan luar Teluk Parepare memiliki sebaran lebih hangat dibandingkan bagian selatan perairan Teluk Parepare (pesisir Kabupaten Barru). Sebaran menunjukkan perairan Teluk Parepare masih dalam kisaran nilai untuk wilayah perairan tropis Indonesia (Kusuma dkk., 2017).

Sebaran salinitas menunjukkan nilai rendah di bagian tenggara Teluk Parepare (pesisir Kabupaten Barru). Kondisi ini berdasarkan aliran air sungai yang masuk ke laut dan menyebabkan salinitas di sekitar muara sungai tersebut (pesisir pertemuan sungai dan laut) lebih rendah dibandingkan lokasi pesisir lainnya. Kondisi hampir serupa juga terlihat di wilayah timur laut Teluk Parepare (Gambar 4b). Hal yang perlu diperhatikan untuk parameter fisika laut di perairan di Indonesia, seperti suhu dan salinitas sangat dipengaruhi oleh kondisi lingkungan sekitarnya, seperti variasi siang dan malam, serta perbedaan angin musiman (musim barat dan timur).

Derajat keasaman dapat digunakan sebagai indikator terjadinya perubahan iklim yang terpantau dari keasaman laut, kondisi keasaman yang tinggi dapat menyebabkan terjadinya hujan asam. Sehingga, pemantauan akan parameter ini secara time series sangatlah diperlukan dalam hal penentuan keasaman laut yang mungkin terjadi dan dapat menyebabkan perubahan kondisi lingkungan yang ada terutama bagi biota laut. Sebaran $\mathrm{pH}$ secara spasial menunjukkan nilai lebih rendah di dalam perairan Teluk Parepare dibandingkan wilayah perairan luar Teluk (Gambar 5a). Nilai ini masih berada di kisaran baku mutu untuk perairan peruntukkan pelabuhan, serta masih tergolong normal untuk kehidupan biota laut yaitu berada pada kisaran 7-8,5 (KemenLH, 2004). 

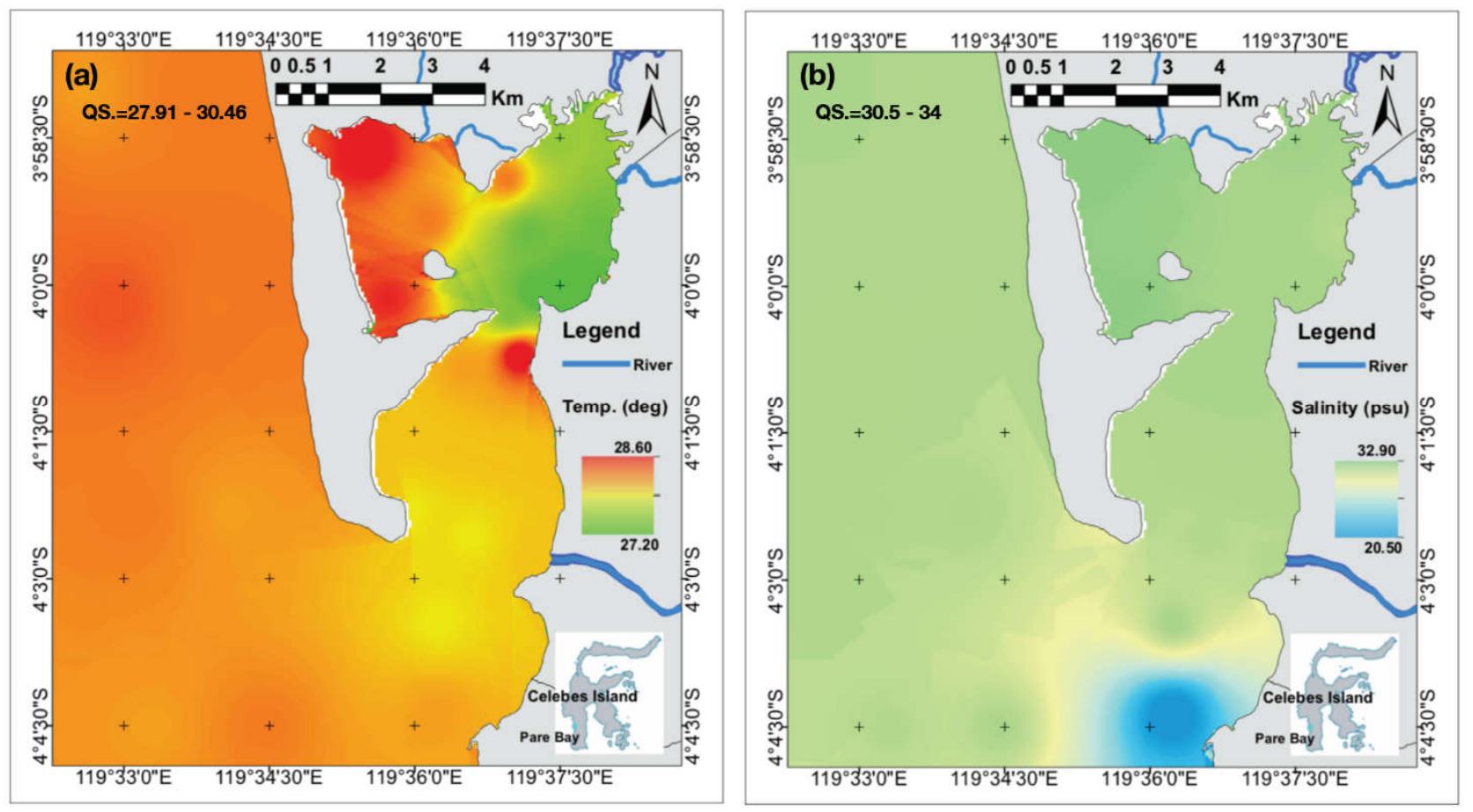

Gambar 4 Sebaran parameter fisik kualitas air: (a) Suhu dan (b) Salinitas
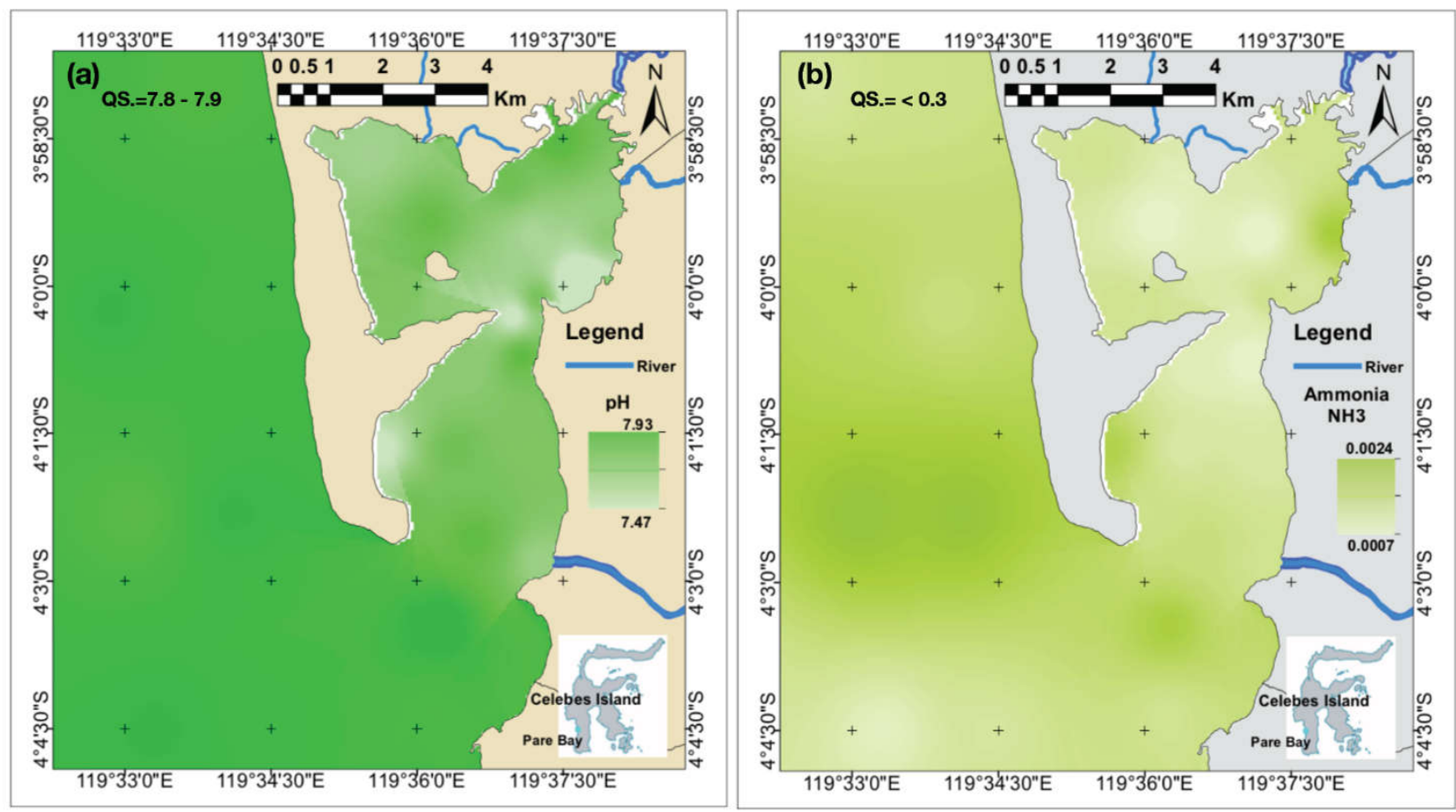

Gambar 5 Sebaran parameter kualitas air: (a) pH dan (b) Konsentrasi Ammonia

Selanjutnya, sebaran konsentrasi ammonia ditunjukkan di Gambar 5b dan pola sebaran nilai tinggi berada di mulut teluk sebelah barat (di luar Teluk Parepare). Menurut Effendi (2003) ammonia adalah parameter pencemar bersifat organik dan berasal dari limbah domestik dan industri, serta limpasan pupuk pertanian. Sumber ammonia di perairan adalah hasil pemecahan nitrogen organik (protein dan urea) dan nitrogen anorganik yang terdapat dalam air, juga berasal dari dekomposisi bahan organik (tumbuhan dan biota akuatik yang telah mati) yang dilakukan oleh mikroba dan jamur. Peningkatan kadar ammonia di laut berkaitan erat dengan masuknya bahan organik yang mudah terurai (dalam hal ini dapat mengandung unsur nitrogen maupun tidak).

Sebaran konsentrasi timbal dan tembaga di Teluk Parepare ditunjukkan di Gambar 6a-6b. Sebaran konsentrasi timbal tertinggi berada di sekitar pesisir Kota Parepare, pesisir Kabupaten Parepare (Gambar 6a) dan hasil ini berkesesuaian dengan hasil Wisha dkk. (2018). 

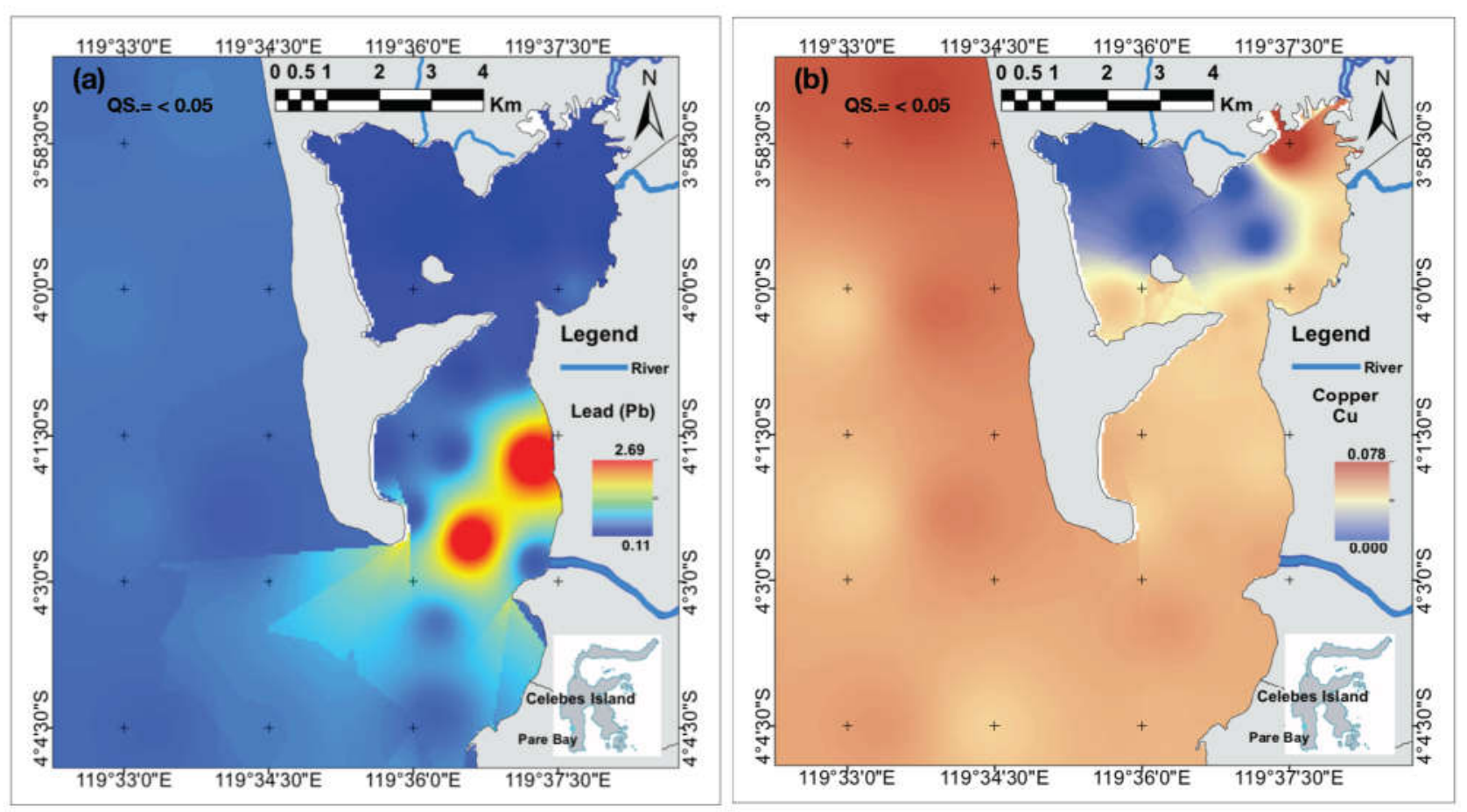

Gambar 6 Sebaran Parameter Kualitas Air Konsentrasi: (a) Timbal dan (b) Tembaga

Akan tetapi penelitian sejenis lainnya memiliki nilai berbeda, konsentrasi $\mathrm{Pb}$ di wilayah Teluk Parepare hasil perhitungan Setiawan dan Subiandono (2015) masih berada di kisaran baku mutu $(0,05$ $\mathrm{mg} / \mathrm{L}$ ). Tingginya konsentrasi timbal di perairan ini berkorelasi dengan tingginya aktivitas pelabuhan (bongkar muat barang dan pengisian bahan bakar), serta limbah bahan bakar (solar) perahu/kapal dengan konsentrasi tinggi di sekitar perairan Teluk Parepare (Wisha dkk., 2018). Penelitian lainnya (Usman dkk. 2013) mengukur kandungan timbal yang berada dalam badan perairan dan sedimen di sekitar wilayah pesisir Pelabuhan Nusantara di Kota Parepare. Nilai konsentrasinya berada berkisar antara 0,0380-0,8240 ppm di badan perairan laut, sedangkan di dalam sedimen berkisar antara 38,9663-60,8982 mg/kg. Hasil tersebut menunjukkan telah melebihi nilai standar baku mutu air laut, dimana 0,05 ppm peruntukkan pelabuhan dan 0,008 ppm peruntukkan bagi biota laut dapat hidup.

Sebaran tembaga di perairan Teluk Parepare juga memiliki nilai di atas baku mutu bagi peruntukkan perairan pelabuhan di beberapa stasiun pengamatan. Kisaran nilai sebaran tembaga adalah 0,043 - 0,078 $\mathrm{mg} / \mathrm{L}$. Sebaran logam terlarut tembaga di lokasi kajian ditunjukkan di Gambar 6b. Tingginya konsentrasi tembaga berada di wilayah barat laut dalam area Teluk Parepare, sedangkan sebaran terendah berada bersebrangan, di timur laut dalam area Teluk Parepare. Logam berat $\mathrm{Cu}$ digolongkan ke dalam logam berat essensial, artinya meskipun merupakan logam berat beracun, akan tetapi dibutuhkan oleh tubuh meskipun dalam jumlah sedikit. Logam berat Cu masuk ke dalam tatanan lingkungan sebagai akibat dari aktivitas manusia, contohnya buangan industri galangan kapal yang memakai $\mathrm{Cu}$ dalam proses produksinya (Supriyantini dan Soenardjo, 2015). Tingginya logam berat ini tidak dapat kita abaikan begitu saja, mengingat pengaruhnya yang sangat berbahaya bagi tubuh kita, dimana logam yang masuk melalui rantai makanan dan terakumulasi dalam tubuh kita akan menyebabkan keracunan, merusak organ tubuh kita dan pada akhirnya dapat menyebabkan kematian (Palar, 2012).

\subsection{Indeks Pencemaran di Perairan Teluk Pare- pare}

Indeks pencemaran di setiap stasiun pengamatan ditunjukkan di Gambar 7 dan sebaran indeksnya di Gambar 8. Hasil perhitungan indeks pencemaran di semua stasiun pengamatan menunjukkan hampir sebagian besar stasiun (14 stasiun, S1-S6, S8-S14, dan S17) memiliki IP cemar ringan, 12 stasiun memiliki IP cemar sedang (S7, S18-S28), dan 2 stasiun memiliki IP cemar berat (S15 dan S16) ditunjukkan di Gambar 7. Sebaran IP juga merepresentasikan kondisi yang sama, karena sebaran IP dihitung berdasarkan parameter kualitas perairan di stasiun-stasiun tersebut (Gambar 8).

Meskipun umumnya IP menunjukkan nilai cemar ringan di perairan Teluk Parepare, akan tetapi IP di S15 dan S16 termasuk dalam cemar tinggi. Kondisi ini berkaitan dengan nilai konsentrasi timbal yang tinggi di kedua stasiun tersebut (Gambar 8). Konsentrasi timbal di kedua stasiun tersebut melebihi baku mutu bagi peruntukkan perairan pelabuhan. Meskipun, konsentrasi tembaga di S16 masih berada di bawah baku mutu (Gambar 8). Stasiun S15 dan S16 berada berdekatan di pesisir Kota Parepare. Kondisi pesisir wilayah ini menjadi sangat riskan untuk dijadikan tempat budi daya perikanan. Hasil penelitian saat ini, bisa menjadi masukkan dan pengembangan dari 
penelitian sebelumnya (Fattah dkk., 2017), yang mana tidak hanya faktor perubahan iklim yang dapat mempengaruhi produksi budi daya perikanan di wilayah tersebut. Peningkatan faktor polutan logam berat di wilayah tersebut akan dapat merubah keseimbangan antara pemanfaatan perairan dan kelestarian di perairan tersebut.

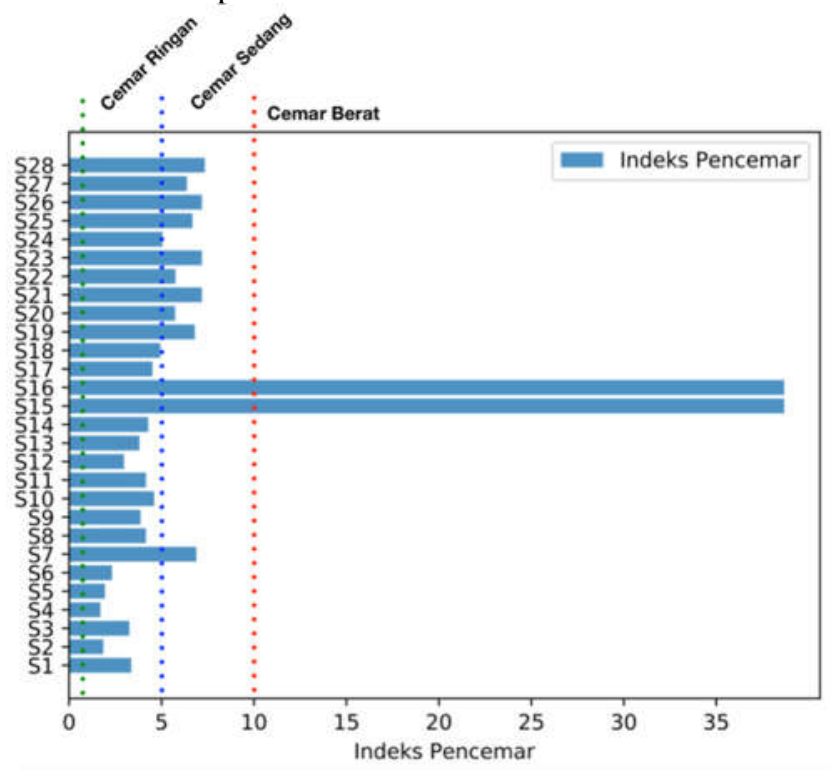

Gambar 7 Indeks Pencemar di Masing-Masing Stasiun Pengamatan

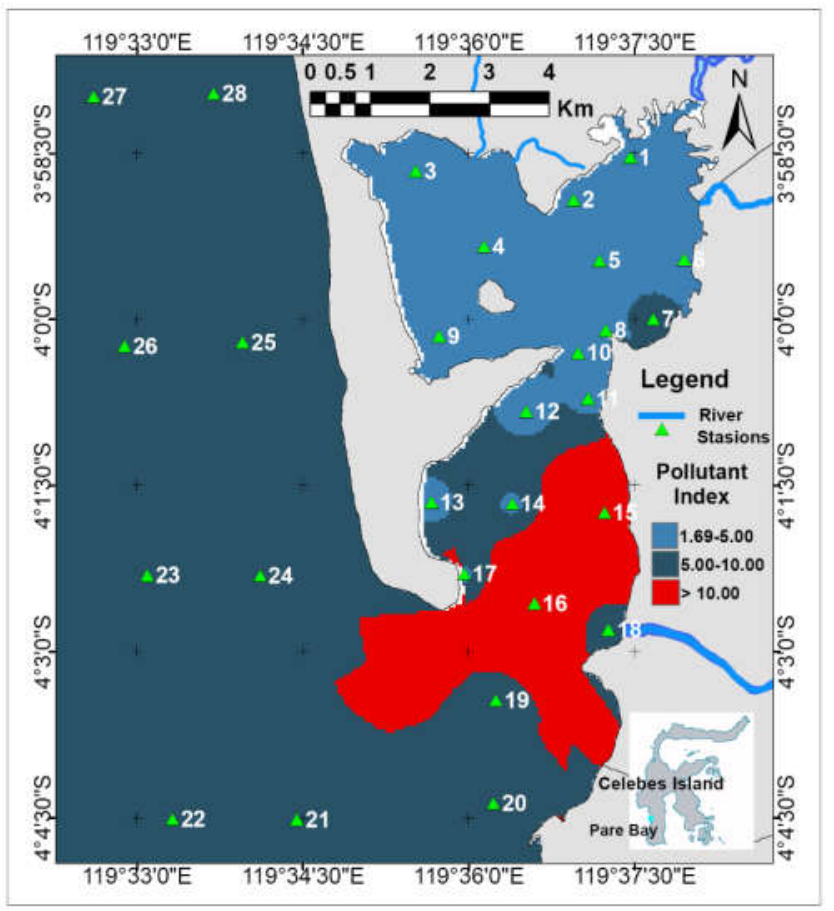

Gambar 8 Sebaran Indekas Pencemar Klasifikasi Berdasarkan KemenLH (2003)

Pola sebaran indeks pencemaran di perairan Teluk Parepare menggambarkan area-area yang tercemar sesuai dengan tingkatannya. Gambar 8 menunjukkan sebaran indeks pencemaran yang merupakan hasil perhitungan dari sebaran parameter kualitas air hasil sampling di lapangan (Gambar 4a-b, Gambar 5a-5b, dan Gambar 6a-6b). Indeks pencemaran dibagi berdasarkan kategori dalam Keputusan
MenLH No. 115 tahun 2003. Hasil indeks menunjukkan minim/tidak adanya area dengan kategori baik (indeks antara $0-1$ ) atau memenuhi baku mutu (IP minimum hasil perhitungan $=1,69$ ). Area dengan kategori tercemar ringan $(1,0<$ IP $\leq 5,0)$ berada di bagian dalam Teluk Parepare. Area tercemar sedang $(5,0<\mathrm{IP} \leq 10)$ umumnya berada di bagian luar Teluk Parepare dan di sebagian dalam Teluk Parepare, pesisir Kabupaten Pinrang (Gambar 8). Sedangkan, area tercemar berat (IP $>10$ ) berada di sekitar pesisir Kota Parepare (sebelah timur area kajian dan bagian dari Kabupaten Parepare).

\subsection{Kaitan Sebaran Parameter Kualitas Air Laut dan Indeks Pencemaran}

Hasil sebaran indeks pencemar (Gambar 8) berkaitan erat dengan pola sebaran logam berat di perairan Teluk Parepare (Gambar 6a-6b). Pola sebaran logam berat, yaitu timbal dan tembaga, menunjukkan nilai yang tinggi di sekitar pesisir Kota Parepare (Stasiun S15 dan S16 di Gambar 8). Pelabuhan Nusantara Parepare (sekitar stasiun S11 di Gambar 8) dan terminal kilang minyak (sekitar S7 di Gambar8), ke dua area tersebut termasuk area tercemar ringan dan sedang.

Terdapat empat pelabuhan di sekitar Kota Parepare yaitu Pelabuhan Nusantara Parepare, Cappa Ujung, Lontange dan Cempae (Pelindo IV, 2016). Pelabuhan Nusantara Parepare merupakan pelabuhan sangat aktif, sebagai tempat berlabuhnya kapalkapal penumpang komersil. Pelabuhan Cappa Ujung dan Lontage (stasiun pengamatan S8 Gambar 8) merupakan perlabuhan dominan sebagai terminal kapal-kapal kontainer, serta peti kemas. Adapun, Pelabuhan Cempae (sekitar stasiun pengamatan S6S7 Gambar 8) merupakan tempat pelelangan ikan (TPI) dan berlabuhnya kapal-kapal penangkap ikan. Di sekitar pesisir stasiun-stasiun tersebut indeks pencemar termasuk ringan dan sedang.

Di antara ke empat pelabuhan di wilayah perairan Teluk Parepare, Pelabuhan Nusantara Parepare merupakan pelabuhan tersibuk. Pelabuhan ini sering digunakan sebagai jalur pelayaran menghubungkan Parepare dengan kota-kota di pesisir Kalimantan, Surabaya dan kota-kota pelabuhan di Indonesia bagian timur (Pelindo IV, 2016). Banyaknya kapal keluar masuk ke Pelabuhan Nusantara Parepare berkorelasi dengan tingginya penggunaan bahan bakar kapal, sehingga kemungkinan besar polutan sisa bahan bakar pun menjadi tinggi. Pembakaran bahan bakar solar (umumnya digunakan kapal-kapal laut) menghasilkan emisi timbal ke udara, kemudian terjadi pengkristalan timbal dan masuk ke perairan dengan bantuan air hujan (Palar, 2012).

Selain itu, industri galangan kapal di sekitar pelabuhan tersebut dapat memberikan sumbangan limbah yang mengandung tembaga. Industri galangan kapal adalah industri fabrikasi, pemelihaaraan, dan reparasi kapal yang melibatkan penggunaan material kimia termasuk logam berat. Proses pemeliharaan 
permukaan kapal melalui pembersihan dan pelapisan permukaan kapal salah satu materialnya menggunakan logam berat tembaga (Dewantara dkk., 2017 dan Hidayat, 2017). Meskipun buangan proses ini telah dikelola dengan menginstal Regenerative Thermal Oxidisers (RTO), akan tetapi tidak menjamin semuanya terkelola sempurna dan tidak terbuang ke perairan sekitarnya.

Sebaran cemaran (Gambar 8) menunjukkan tingginya cemaran di pesisir Kota Parepare (S15 dan S16), sedangkan lokasi Pelabuhan Nusantara dan kilang minyak berada di bagian utara dari pesisir Kota Parepare (sekitar stasiun S11, S6-S8). Perbedaan topografi di kedua wilayah tersebut, memungkinkan tingginya cemaran tidak di wilayah yang berdekatan dengan lokasi pelabuhan dan kilang minyak. Wilayah pesisir Kota Parepare berkedalaman lebih dangkal dibandingkan area pesisir sebelah utara yang berdekatan dengan Pelabuhan (Wisha dan Heriati, 2016a). Perairan pesisir lebih dangkal memungkinkan lebih tingginya konsentrasi polutan. Perairan dangkal memiliki proses turbulensi dasar yang insentif, sehingga logam berat dalam sedimen lebih banyak tersuspensi atau terlepas ke kolom air (Wisha dan Heriati, 2016b).

Selanjutnya, kondisi arus yang dipengaruhi pasang surut menunjukkan arah arus masuk dan keluar dari Teluk Parepare. Arus masuk ke Teluk Parepare bergerak ke arah utara, sedangkan arus keluar dari Teluk Parepare bergerak ke arah selatan. Kondisi arus arus pasang surut sangat besar pengaruhnya (Wisha dan Heriati, 2016a), dan bila tidak terjadi pertukaran air dengan baik, maka polutan tersebut dapat terperangkap di area pesisir Kota Parepare dan mencemari area tersebut. Selain itu, ironisnya wilayah pesisir Kota Parepare berdekatan dengan area budidaya para nelayan lokal (Fattah dkk., 2017), yang juga dapat memberikan sumbangan limbah di wilayah tersebut.

Berdasarkan hasil IP di stasiun dan sebarannya menunjukkan ada stasiun/area dengan kondisi cemar ringan, akan tetapi dengan konsentrasi logam berat (timbal) yang melebihi baku mutu (contoh: S11 sd. S14). Kondisi ini menunjukkan metode IP masih perlu dikembangkan untuk dapat merepresentasikan perbedaan penafsiran cemaran tersebut. Penelitianpenelitan IP sebelumnya (Hamuna dkk., 2018 dan Bachtiar dkk., 2004) belum memasukkan parameter logam berat dalam perhitungan indeksnya. Penelitian oleh Tanjung dkk. (2019) memasukkan parameter logam berat dalam perhitungan indeksnya dan konsentrasi logam berat di wilayah kajian memberikan hasil di bawah baku mutu yang ditentukan. Akan tetapi, konsentrasi nitrat $\left(\mathrm{NO}_{3}\right)$ dan fosfat $\left(\mathrm{PO}_{4}\right)$ dalam penelitian tersebut memiliki nilai di atas baku mutu dan hanya termasuk dalam IP cemar ringan. Hasil penelitian tersebut menunjukkan kendala IP yang sama dengan penelitian yang dilakukan saat ini.

Salah satu penelitian pengembangan IP telah diaplikasikan untuk menganalisis kontaminasi logam berat pada air tanah (Selvan dkk., 2015). Penelitian 280 tersebut memberikan bobot pada parameter logam berat berdasarkan kualitas standar air minum (sesuai rekomendasi pemerintah dan WHO). Bobot bernilai antara 0 dan 1 dan dipilih sesuai dengan penting atau berbahaya tidaknya parameter tersebut sesuai peruntukkannya, dalam hal ini sebagai air minum. Solusi pemberian bobot ini dapat mengantisipasi kelemahan IP yang diaplikasikan dalam penelitian saat ini. Sehingga, perlu dikembangkan penelitian lanjutan yaitu, melakukan perhitungan IP dengan pembobotan pada masing-masing parameter kualitas air yang dikaji.

\section{Kesimpulan}

Parameter kualitas air yang dikaji di Teluk Parepare mengikuti peraturan Kementerian Lingkungan Hidup No. 51 tahun 2004 dan baku mutu wilayah peruntukkan perairan pelabuhan. Parameter tersebut adalah suhu, salinitas, $\mathrm{pH}$, ammonia, timbal dan tembaga dan pengambilan sampel di 28 stasiun mewakili area perairan Teluk Parepare. Hasil kajian menunjukkan kondisi parameter suhu, salinitas, pH dan ammonia umumnya di semua stasiun pengamatan berada di kisaran baku mutu yang ditentukan. Sedangkan, konsentrasi logam berat, yaitu timbal dan tembaga di sebagaian besar stasiun pengamatan berada di atas baku mutu yang ditentukan. Konsentrasi timbal berada di kisaran nilai 0,11 - 2,69 mg/L, sedangkan konsentrasi tembaga berada di kisaran nilai 0,043 - 0,078 mg/L. Indeks Pencemar (IP) dihitung mengikuti peraturan Kementrian Lingkungan Hidup No. 115 tahun 2003 dan hasilnya berada di kisaran nilai 1,69-38,66. Terdapat 14 stasiun (S1-S6, S8-S14, dan S17) pengamatan di lapangan dengan indeks cemar ringan $(1,69<\mathrm{IP} \leq 5,0), 12$ stasiun (S7, S18-S28), dengan cemaran sedang $(5,0<\mathrm{PI} \leq 10)$, dan 2 stasiun (S15 dan S16) dengan cemaran berat (PI>10). Sebaran menunjukkan wila-yah dengan indeks cemar ringan berada di dalam perairan Teluk Parepare, cemar sedang di luar perairan Teluk Parepare, dan cemar berat di sekitar pesisir Kota Parepare dan sekitarnya. Sebaran cemar berat berada di pesisir Teluk Parepare dan berkore-. lasi dengan tingginya kandungan logam berat di beberapa stasiun yang berdekatan dengan wilayah pesisir tersebut. Kondisi ini menunjukkan aktivitas pelabuhan dan galangan kapal, serta buangan limbah domestik di sekitar perairan Teluk Parepare telah memicu pencemaran di perairan tersebut. Perlu adanya perhatian khusus dari pemerintah daerah setempat terkait pencemaran ini, dikarenakan pentingnya penataan ruang yang berbasis lingkungan agar pembangunan dapat berjalan secara berkelanjutan. Penelitian ini dan penelitian lainnya terkait pencemaran di perairan Teluk Parepare dapat digunakan sebagai identifikasi dan estimasi pencemaran yang sudah ada, serta memberikan masukan untuk membenahi wilayah tersebut. Selain itu, para pemegang kepentingan memiliki tanggungjawab dalam melaksanakan 
pengelolaan kualitas air dan pengendalian pencemaran air di perairan Teluk Parepare.

\section{UCAPAN TERIMA KASIH}

Penelitian ini dapat terselenggara dari kegiatan penelitian APBNP pemantauan kondisi pelabuhan perikanan 2015. Untuk itu diucapkan terima kasih untuk Pusat Penelitian dan Pengembangan Sumber Daya Laut dan Pesisir (P3SDLP) untuk DIPA anggaran 2015, PPI Cempae, dan semua pihak yang telah membantu dalam pelaksanaan penelitian ini.

\section{DAFTAR PUSTAKA}

Amaliah, A., Dewa, S., dan Idrus, M., (2018), Analisa Kapasitas Optimal Lapangan Penumpukan di Pangkalan Lontangnge Pelabuhan Parepare, Jurnal KPE-UnHas, Vol. 22, No. 1.

Bengen, D.G., (2004). Ragam Pemikiran. Menuju Pembangunan Pesisir dan laut Berkelanjutan Berbasis Eko-sosiosistem. Pusat Pembelajaran dan Pengembangan Pesisir dan Laut (P4L). Bogor

Brotowijoyo, M. D., Dj. Tribawono., dan E. Mulbyantoro., (1995), Pengantar Lingkungan Perairan dan Budidaya Air. Liberty Yogyakarta.

Childs, C., (2004), Interpolating surface in ArcGIS Spatial Analysis, ESRI Education Services.

Dahuri, R., J. Rais, S. P. Ginting, dan M. J. Sitepu., (2003), Pengelolaan Sumberdaya Wilayah Pesisir dan Lautan Secara Terpadu, Cetakan Ketiga, Edisi Revisi, Jakarta: PT. Pradnya Paramita.

Dewantara, F.A., Setiani V., dan Rizal M.C., (2017), Perancangan Tempat Penyimpanan Sementara (TPS) Limbah Bahan Berbahaya dan Beracun (B3) Pada Perusahaan Galangan Kapal, Proceeding $1^{\text {st }}$ Conference on Safety Engineering and Its Application, Prodi Studi D4 Teknik Keselamatan \& Kesehatan Kerja-Politeknik Perkapalan Negeri Surabaya, ISSN No. 2581 - 1770.

Diposaptono, S., (2016), Membangun Poros Maritim Dunia Dalam Perspektif Tata Ruang Laut, Perpustakaan Nasional, ISBN: 978-979-1291-55-2.

Effendi, H., (2003), Telaah Kualitas Air Bagi Pengelolaan Sumber Daya dan Lingkungan Perairan, Kanisisus Publiser, Yogyakarta.

Fattah, M.H., Busaeri, S.R., Kasnir, M., dan Siswanto, (2017), Changes in Managerial Decision on Pond Management to Adapt to Climate Anomalies in the Coastal Area of Pare-Pare Gulf, District of Pinrang, IOP Conf. Ser.: Earth Environ. Sci. 79012032.

GESAMP (IMO/FAO/UNESCO-IOC/WMO/WHO/IAEA/UN/ UNEP Joint Group of Experts on the Scientific Aspects of Marine Environmental Protection), 1996. The contributions of science to coastal zone management. Rep.Stud.GESAMP, (61):66p

Hamuna, B., Tanjung, R.H.R., Suwito, Maury, dan H.K., Alianto., (2018), Kajian Kualitas Air Laut dan Indeks Pencemaran Berdasarkan Parameter Fisika-Kimia Di Perairan Distrik Depapre, Jayapura, Jurnal Ilmu Lingkungan. Program Studi Ilmu Lingkungan Sekolah Pascasarjana UNDIP, Volume 16 Issue 1 (2018): 35-43.

Hidayat, T., (2017), Faktor-Faktor di Industri Galangan Kapal yang Dapat Berkontribusi pada Isu Perubahan Iklim, SPECTA Journal of Technology, Vol. 1 No. 2, JulyAugust 2017, ISSN: 2549-2713.

KemenLH., (2003), Keputusan Menteri Negara Lingkungan Hidup, Nomor 115 Tahun 2003, Tentang Penentuan Status Mutu Air.
KemenLH., (2004), Keputusan Menteri Negara Lingkungan Hidup, Nomor 51 Tahun 2004, Tentang Baku mutu Air Laut.

Kusuma, D.W., Murdimanto, A., Aden, L.Y., Sukresno, B., dan Hanintyo, R., (2017), Sea Surface Temperature Dynamics in Indonesia, IOP Conf. Series: Earth and Environmental Science 98, doi :10.1088/1755-1315/ 98/1/012038.

Malik, A.A., Nurhapsa, dan Tabsir, M.K., (2018), Penggunaan Alat Bantu pada Kelompok Nelayan Penangkap Ikan Pelagis Campuran di Kabupaten Barru, Jurnal Dedikasi, Vol. 20, No. 1, Oktober 2018.

Mappagala, A.B., (2017), Penataan Ruang Kawasan Tepi Pantai Mattirotasi dalam Menunjang Kepariwisataan di Kota Parepare, Jurusan Teknik Sipil dan Perencanaan Wilayah Kota, Fakultas Sains dan Teknologi UIN Alauddin Makassar.

Palar, H., (2012), Pencemaran dan Toksikologi Logam Berat, Cetakan ke-4, Penerbit Rineka Cipta, Jakarta.

Pelindo IV, (2016), Pelabuhan Kota Parepare, Retrieved February 10, 2020, from http://inaport4.co.id/ branch/read/1/17.

Putri, M.R., Setiawan, A., dan Safitri, M., (2015), Variation of ocean $\mathrm{pH}$ in the Indonesia waters, The 5th International Conference on Mathematics and Natural Sciences, AIP Conf. Proc. 1677, 060021-1-060021-4; doi: 10.1063/1.4930701.

Qin, R. dan Lin, L., (2017), Development of a GIS-based integrated framework for coastal seiches monitoring and forecasting: A North Jiangsu shoal case study. Computers and Geosciences, http://dx.doi.org/10. 1016/j.cageo.2017.03.010.

Selvam, S., Venkatramanan, S., \& Singaraja, C. (2015). A GISbased assessment of water quality pollution indices for heavy metal contamination in Tuticorin Corporation, Tamilnadu, India. Arabian Journal of Geosciences, 8, 10611-10623.

Setiawan, H. dan Subiandono, E., (2015), Konsentrasi Logam Berat pada Air dan Sedimen di Perairan Pesisir Provinsi Sulawesi Selatan, Forest Rehabilitation Journal Vol. 3 No. 1, Maret 2015: 67-79.

SNI (Standar Nasional Indonesia), (2010), SNI7644:2010 Basis Data Spasial Oseanografi: Suhu, Salinitas, Oksigen Terlarut, Derajat Keasaman, Turbiditas, dan Kecerahan, Badan Standar Nasional (BSN), Jakarta.

Supriyantini, N. dan Soenardjo, (2015), Kandungan Logam Berat Timbal (Pb) Dan Tembaga (Cu) Pada Akar Dan Buah Mangrove Avicennia marina Di Perairan Tanjung Emas Semarang. Jurnal Kelautan Tropis September 2015 Vol. 18(2):98-106.

Tanjung, R.H.R., Hamuna B., dan Alianto, (2019), Assessment of Water Quality and Pollution Index in Coastal Waters of Mimika, Indonesia. Journal of Ecological Engineering, Vol. 20, Issue 2, February 2019, pages:87-94. https://doi.org/10.12911/22998993/ 95266.

Toyoda, T., Fujii, Y., Kuragano, T., Matthews, J.P., Abe, H., Ebuchi, N., Usui, N., Ogawa, K., \& Kamachi, M. (2015), Improvements to a global ocean data assimilation system through the incorporation of Aquarius surface salinity data. Quarterly Journal of the Royal Meteorological Society, Vol. 141, issue 692, pages: 2471-2922, https://doi.org/10.1002/ qj.2561.

UNEP (2015), The Emissions Gap Report 2015, United Nations Environment Programme (UNEP), Nairobi.

Wisha, U.J. dan Heriati, A., (2016a), Bathymetry and Hydrodynamics in Pare Bay Waters During Transitional Seasons (September-October), 
OmniAkuatika, 12 (2): 1-10, 2016, ISSN: 1858-3873 (print), 2476-9347 (online).

Wisha, U.J. dan Heriati, A., (2016b), Analisis Julat Pasang Surut (Tidal Range) dan Pengaruhnya Terhadap Sebaran Total Sedimen Tersuspensi (TSS) di Perairan Teluk Pare, Jurnal Kelautan, Volume 9, No. 1, April 2016, ISSN: 1907-9931 (print), 2476-9991 (online), http://journal.trunojoyo.ac.id/jurnalkelautan.
Wisha, U.J., Heriati, A., Ramdhan, M., Mustikasari, E., Mutmainah, H., dan Ilham, I., (2018), Spatial Distribution of Dissolved Heavy Metals $(\mathrm{Hg}, \mathrm{Cd}, \mathrm{Cu}, \mathrm{Pb}$, Zn) on the Surface Waters of Pare Bay, South Sulawesi, ILMU KELAUTAN: Indonesian Journal of Marine Sciences, vol. 23, no. 4, pp. 199-206, Jan. 2019. https://doi.org/10.14710/ik.ijms.23.4.199-206. 